\title{
The Effect of Affective Organizational Commitment, Job Satisfaction, and Employee Engagement on Job Happiness and Job Performance on Manufacturing Company in Indonesia
}

\author{
UNGGUL KUSTIAWAN, PARDAMEAN MARPAUNG, UNIK DWI LESTARI*, \\ EGI ANDIYANA \\ Esa Unggul University \\ Jalan Arjuna Utara No.9, Kebon Jeruk, Jakarta, 11510 \\ INDONESIA
}

\begin{abstract}
This study examines the effect of affective organizational commitment, job satisfaction, and employee engagement on job happiness and employees' performance in a manufacturing company. The research sample is the employee with a minimum of two years of tenure at a manufacturing company. This research is quantitative research using the Structural Equation Model (SEM) method. Results show that job satisfaction, employee engagement, and affective organizational commitment play a vital role in improving employee happiness performance at working place. This study utilized a total of 275 questionnaires that were administered to respondents at a manufacturing company in Indonesia from May until July 2021. Research respondents were selected using the purposive sampling method. These findings may guide the implementation of human resources or other organization management in the manufacturing industry. For instance, they may use job happiness (mental well-being) to predict employee behaviors and then formulate recruitment policies that will help maintain employee happiness and satisfaction. This research aims to add information on human resources management science and positive managerial implications on employee happiness and performance in the Indonesian manufacturing sector.
\end{abstract}

Key-Word: Affective Organizational Commitment, Job Satisfaction, Job Performance, Employee Engagement, Manufacturing

Received: April 17, 2021. Revised: January 12, 2022. Accepted: January 26, 2022. Published: February 10, 2022.

\section{Introduction}

Job happiness and job satisfaction of workers are important for the management of an organization where this can be seen from several studies conducted by researchers, academics, and management leaders [1]. In addition, happiness at work is a critical topic growing and requires attention [2]. Then when it is viewed from the performance aspect, the happiness of workers can improve the performance of workers [3] - [5]. Moreover, it becomes interesting to be discussed and researched since there is no single or dominant factor that can determine the job happiness of workers. Further, the level of satisfaction in family life affects workers' happiness more than satisfaction obtained at work [6] [7]. Hence, it is necessary to have a balanced personal life, family, and social environment and a sense of pleasure at work. It is the basis that continuously produces positive affective feelings to feel a meaningful life [8].

Along with the increasing satisfaction experienced by employees through total rewards perception, it is known to affect job happiness mediated by employee engagement [9]. In another aspect, intensive knowledge is very important in determining the happiness of workers in the workplace because it can provide good results and become a source of pride [10] for the worker to tackle the difficulties at the job site. Meanwhile, transformational, and inspirational leadership is also considered one factor that encourages happiness [11]. Employee satisfaction can also be derived through company activities, convincing the 
employees that there is organizational goodwill in social activities [12].

Moreover, several important factors affect employee happiness, including job satisfaction, affective organizational commitment, and employee engagement [13], which focus on this study. Several previous studies explained that happiness and satisfaction from nurses are known to close associations [14]. Job satisfaction is expected to boost job happiness in the workplace by increasing positive attitudes by combining cognitive and affective elements in providing a perspective on job characteristics [11].

In addition, job satisfaction affects job happiness, job performance, and turnover intention in workers in the oil and gas industry [5]. Furthermore, employment conditions, communication, working relations, job characteristics, and organizational culture are also known to affect job happiness [15]. [16], also claim that the amount of time and energy spent at work also affects workers' happiness, viewed from the social context, so workplace conditions become essential. It should also be considered important to the relationship between affective organizational commitment and job performance [17].

Numerous previous studies have explained the relationship between job satisfaction and employee engagement with job performance [18] - [21]. However, not many studies demonstrated the relationship between job satisfaction, affective organizational commitment, and employee engagement on job happiness and employee performance simultaneously in Indonesia, especially for manufacturing companies in the Tangerang Industrial area, Banten province Indonesia. Therefore, this study intends to explore the effect of job satisfaction, affective organizational commitment, and employee engagement on job happiness and the impact of job satisfaction, job happiness, and employee engagement on employee performance.

\section{Literature Review}

\subsection{Affective Organizational Commitment}

Organizational commitment is a positive experience that is believed to acknowledge organizational values at work that tends to create an emotional attachment to the organization [22]. Commitment can be understood as a perceived obligation to remain in the organization by employees [23]. Moreover, commitment arises when workers feel that the company is attractive in various ways that encourage cognitive and feelings or bonds [17]. Organizational commitment consists of three important components, namely affective, normative, and continuous [24]. Of these three components, the most favored in organizational commitment is affective because it represents the emotional bond inherent in organizational members to remain part of the organization [24]. Further, from the three components of organizational commitment, only affective organizational commitment is the most effective because emotional bonds are formed. Workers tend to work hard, exert maximum ability to show more work performance, and contribute better value to the organization [25].

Affective organizational commitment has multidimensional traits that be affected by the workplace circumstance [26], leadership [27], leadership style [28],organizational support [29] for instance: through training [30] - [31], work climate [32] and benefits [33]. Therefore, organizations must continue to try to recognize effects that may decrease the affective organizational commitment, which can lead to the loss of valuable employees in the organization [34] instead of committed ones will remain active and consistent in all organizational programs to maintain the reputation and goals of the organization [35].

\subsection{Job Satisfaction}

Job satisfaction is defined as a response to perceptions of job characteristics [11]. Job satisfaction is an essential parameter to the organization's success [36]. Especially for the employees in manufacturing companies [37]. Job satisfaction is perceived as employees' response to their work manifested in the form of positive behavior towards norms determined by the organization. Job satisfaction is obtained through responses to which employees like the job [38]. The reaction is the result of perceptions that are measured by how well the work is done by employees [39]. Moreover, job satisfaction is employees' general feelings about their work and work elements such as 
work environment, working conditions, fair rewards, and communication with colleagues [40].

Job satisfaction from employees is very influential to their productivity. Then job satisfaction is believed to minimize employee retention [41]. Job satisfaction consists of affective (emotional condition) and cognitive (satisfaction). Job satisfaction can be increased by having affective job satisfaction. Meanwhile, cognitive job satisfaction is needed to help evaluate job aspects logically [41]. However, the measure of job satisfaction must combine affective and cognitive elements with supporting productivity [38].

The magnitude of job satisfaction is determined by countless factors and conditions [42]. Factors that can affect job satisfaction include leadership style [43], promotion, salary, career opportunities, payroll system, compensation [44] - [46], bonuses, organizational conditions, leadership [47], flexible working hours, good work team, working environment conditions [48][49] and nature of work [50]. Further, expressing dissatisfaction is hard to be seen but can be felt [51]. The negative consequences of dissatisfaction at the surface level are characterized by decreased loyalty, increased absenteeism, and a high number of workplace accidents, which is the reason for the importance of job satisfaction.

\subsection{Employee Engagement}

Employee engagement is characterized by employees' efforts to express themselves when doing their jobs [52]. There are needs to be a clear distinction between engagement in work and organization because the measure of employee engagement must count from performance and organization. Therefore, it is essential for employees to work and the organization [53]. Meanwhile, the part of a person is very diverse, and it is not limited by the job [54]. Further, Employee engagement is a total attachment psychologically, cognitively, and emotionally at work and recognition of the organization and work values [55].

Employee engagement with the organization is reflected by having a sense of enthusiasm [56], the optimism inherent in their work [57], and this is what distinguishes whether employees can enjoy their role at work or not [58]. Employees who already feel attached to the company will demonstrate several potential behaviors for the organization. It includes going the extra mile, praising the company, collaborating, proactive problem-solving, over time, helping co-workers, sharing knowledge, offering creativity, and participating in organizational dialogue [59].

The reflection of employee engagement and role is the positive involvement of the organization's physical, cognitive, and emotional elements at work [60]. Moreover, engagement is a psychological condition that includes several factors such as interest, absorption, enthusiasm, and enthusiasm whose size can be embodied by several categories, including job satisfaction, commitment, and work involvement [61].

\subsection{Job Happiness}

According to Merriam-Webster, happiness is defined as a state of well-being, health, and happiness. It can also be construed as a condition of comfort, health in the Oxford lexicon dictionary. And some opinions define that happiness as a positive state resulting from life experiences and cognitive assessments of life [62].

Happiness has two views: the pleasure of life by observing things that satisfy oneself, known as hedonic. The other view is on the value and benefits of energy known as eudemonic [63]. Job happiness is not limited only to personal life but can also be experienced in the work environment [64]. The measure of worker happiness at work depends on the wants and needs [65] obtained through work activities. Job happiness is a combination of the comfort of the work environment in the organization and the meaning of work based on the type of work. The approach to job happiness can also be applied hedonic and eudemonic [66].

\subsection{Job Performance}

Measuring job performance in an organization using precise apparatus is very important. It is essential because of the characteristics of the job and its variations [67]. Individual job performance is not only emphasized on the nature of the job but also on the construction of controlled behavior that has an active and positive contribution to the organization [68]. In its definition, job performance can be interpreted as an individual's attitude or behavior that is relevant to the goals of an organization in carrying 
out tasks that require expertise, experience, good mood, and motivation [69].

An organization must look at performance from several dimensions. At least three essential measures become the controlling tools in ensuring that individual performance is still excellent or counterproductive, namely: task performance, contextual performance, and counterproductive behavior. The three dimensions above have different sizes. Task performance serves to measure technical ability in completing a given task. Contextual performance helps measure individual behavior that supports the organization, social environment, and psychological environment. And counterproductive behavior serves to measure individual behavior that endangers the survival and reputation of the company. Performance emphasis is not always on results but on works attitudes [69].

Suggested three slightly different performance dimensions: task performance, adaptive performance, and contextual performance [70]. Then version is defined as the capability of employees to carry out the workload assigned according to the resources provided at the work location because Individual work results are closely related to factors like the workplace, work motivation, and the ability to do work [71].

\section{Hypotheses Development}

\subsection{Affective Organizational Commitment on Job Happiness}

Organizational commitment is an important variable to understand the behavior of organizational members that can potentially lead to consequences that benefit the organization and at the same time harm the organization [72]. Disloyalty is one element that can be detrimental in organizations [73][74].

Affective organizational commitment is not only an emphasis on loyalty to the organization but how executive members can perform more. It is not based on what will be received from the organization or the encouragement of the necessities of life. Instead, the relationship between affective organizational commitment and job happiness lies in the worker's response to the support of the corporate environment and the workplace, an extrinsic element [75].

Some previous studies of affective commitment are also strongly correlated and consistent with organizational-relevant and employee-dependent outcomes, whereas the relationship between these outcomes is normative and continual commitment. Each depends on factors outside the individual (e.g., social and labor market quality) tend to be inconsistent and not as robust [76][77][78]. Meanwhile, individuals will show a change in concern with increasing organizational commitment[79] [80]. It is for this reason that many researchers have focused on affective commitment, from the three forms of organizational commitment [76], [80] - [84] in terms of the various factors that exist in the organization and the employees themselves affect job satisfaction. Thus, the hypothesis is:

$H_{1}$ : Affective organizational commitment increases job satisfaction.

\subsection{Job Satisfaction on Job Happiness}

Job satisfaction has a long history as an independent and dependent variable in organizations. These variables are cognitive and affective; The construction of happiness in the workplace is formed from several aspects, including job satisfaction, work engagement, commitment [86]. Another argument said that job satisfaction responds to the perspective of work characteristics [11]. It means that the response can be in the form of positive or negative behavior. The measure of job satisfaction requires an evaluation of job features, responses about work, and emotional experiences at work and differs according to the vision, mission, organizational transparency, and social equality [87].

Job satisfaction and happiness have a positive relationship with an equilibrium between work situations and family life [7]. Happiness in the workplace needs stimulation because it will psychologically motivate work, increase performance, and work consequences, and indicate mental well-being, improving motivation, work performance, and job satisfaction [88]. Increased job satisfaction is based on salary, promotion opportunities, co-workers, working conditions, communication, personal growth, security, and work environment and provides psychological and mental satisfaction [88] [89]. Job happiness is produced by deep job satisfaction through good work, good coworkers, and no less important is the recognition from parties outside the individual, both leaders and organizations in general. 
In addition, other studies have found that factors that can affect job satisfaction provide such as promotions, salaries, career opportunities, payroll systems, compensation [90] - [92], bonuses, organizational conditions, leadership, flexible working hours, good work team, working environment conditions [94][95][96] and nature of work [97]. Moreover, expressing dissatisfaction is not easy to see but can be felt [51]. The negative consequences of job dissatisfaction, such as decreased loyalty, increased absenteeism, and the number of work accidents, often surface as reasons for the importance of job satisfaction. On the other hand, happy workers are more dedicated and engaged in work, are more committed to their work, and exhibit stronger performance [85], [96] - [98]. So, the hypothesis is proposed:

$\mathrm{H}_{2}$ : Job satisfaction increases job happiness.

\subsection{Employee Engagement on Job Happiness}

Organizations must always realize that employee engagement is a challenge that must always receive attention, especially in human resources with high talent, because it will significantly affect its continuity [101]. A measure of employee engagement is rationally and emotionally willing to remain in the company and dedicated to their work [102]. Employee engagement links individual conditions and states of mind in positively understanding and fulfilling a career. It is characterized by absorption, dedication, and strength and is an asset if appropriately managed [103].

This condition is a concept that examines the psychological side that involves emotional, cognitive dedication to work more focused [104]. But it does not mean workaholism because it can cause individuals to be trapped in personal goals or interests, namely happiness that can be felt at work [105]. Controlled psychological conditions will create employee attachment through the needs handled by employees and appear high trust in company policies that will not harm the workers. Moreover, the involvement of members of the organization must be in synergy with the goals and interests of the company. Employees will feel that their existence, work results are noticed by the organization so that there is a sense of calm and happiness in the workplace [106]. Further, employee involvement will increase satisfaction [107]. Then, we hypothesized:

\section{$H_{3}$ : Employee engagement increases job happiness.}

\subsection{Job Satisfaction on Job Performance}

High employee performance cannot be detached from employee job satisfaction. It is because maximum work results are only found from satisfied employees [108]. This supports the previous opinion that an organization must ensure job satisfaction among its employees [109]. Job satisfaction is essential for organizations because job satisfaction is a collection of individual perceptions of employees in the company that will affect how they behave at work [110]. Satisfied employees will have attitudes and behaviors determined and regulated by the organization [111]. The above opinion supports previous research [112]. In general, employee work performance is related to behavior correlated with organizational goals, which are entirely the responsibility of employees [113].

Several phenomena that occur in organizations that affect job satisfaction such as promotions, salaries, career opportunities, payroll systems, compensation [91] [92] [93], bonuses, organizational conditions, leadership, flexible working time, good work team, working environment conditions [95][96] and nature of work [97].

Several studies have shown a very close association between job satisfaction and performance [5] [114] [115] [116]). And the relationship with organizational performance is very adjacent because it is related to the activities and tasks carried out by employees effectively and efficiently and determines how much employees contribute to the organization. Among employee contributions are the quantity of output, work attendance, and accommodative attitude [117]. Further, employees' financial or non-financial results, which are closely related to organizational performance and success, are also reflected in employee performance [118]. Moreover, employee satisfaction has a significant effect on improving employee performance [108] [119]. Thus, the hypothesis is proposed:

$\mathrm{H}_{4}$ : Job satisfaction increases job performance.

\subsection{Employee Engagement on Job Performance}

Changes in strategy are significant to be able to respond to customers. A company needs to make a company-oriented organization and transform it into an organization that prioritizes the customer. It is 
undeniable that the strategy will not succeed if there is no organizational commitment to constantly improving its human resources [120]. Hence, performance improvement is closely related to the level of commitment of an organization in enhancing the reward system that can meet the intrinsic and extrinsic needs of employees, increasing employee involvement, and making the employees the center of all activities in the company [121].

Employee involvement is the highest commitment employees can give to the organization [60]. Although there is a sense of enthusiasm[122] [123] and optimism about their work [124], the roles performed by employees can be different due to different psychological states [125]. Hence, the quality of involvement will be formed on both sides, the employee and organization side [105]. It means a need for a synergistic relationship between the organization and its members. Or somewhat between workers and companies. Employee involvement must be driven by the company's commitment to understanding and meeting individual needs simultaneously intrinsic and extrinsic.

Several previous studies have shown that highly committed employees want to stay with their current company and work for organizational goals so, they are less likely to leave the company [126]. Engaged employees tend to exhibit positive organizational outcomes, including more customer satisfaction, higher productivity and profits, lower turnover intentions [103], do more [127], are highly committed [127], and have a sense of pleasure at work and job happiness [128]. Increased satisfaction in the workplace will improve organizational performance and company branding [129]. With the involvement felt by employees, they will voluntarily try to do their best through behavior and work results, encouraging individual performance.

Empirical evidence from several previous researchers shows the relationship between employee engagement and organizational performance, and the factors that increase employee engagement with improving employee performance are positive [130] [131] [132][133][134] [135] [136] [137] [138] [139][140]. Thus, we hypothesized:

$H_{5}$ : Employee engagement increases job performance.

\subsection{Job Happiness on Job Performance}

One of the essential elements in maintaining the company's operations is maintaining its employees' job performance. The ability of a company to survive is determined by the contribution of increasing employee performance obtained through employee responses in achieving organizational goals that are realized through behavior and work results [141]. The behavior in question is individual behavior relevant to organizational goals, namely individuals who, in carrying out tasks, use their expertise, experience, good attitude, and motivation [69].

Several other researchers also added the same thing that improved working conditions and environments would encourage the creation of happiness [142] [143][144] [145] [146][147] [103]. In addition, a developed workplace will open more opportunities and expectations for employees to grow, fulfill their needs and prosper [148].

Happy employees at work can set targets and strive to achieve them [149], meaning an inner drive and a sense of pride in their work [150]. Further, work happiness can be obtained through employment, recognition by the leadership, social conditions in the organizational environment [62]. Some researchers found that having a job-happiness relationship will improve work quality and results [151]. Employees will maintain attendance and behave loyally to the organization according to the opinion of previous researchers, it will enhance job performance, of course, by getting happiness at work positively affects performance [5], [101], [140], [144], [149] - [154]. So, the hypothesis is proposed:

$H_{6}$ : Job happiness increases job performance.

Based on the above hypothetical framework, the research model can be described as shown in Figure 1 below: 
WSEAS TRANSACTIONS on BUSINESS and ECONOMICS DOI: $10.37394 / 23207.2022 .19 .52$

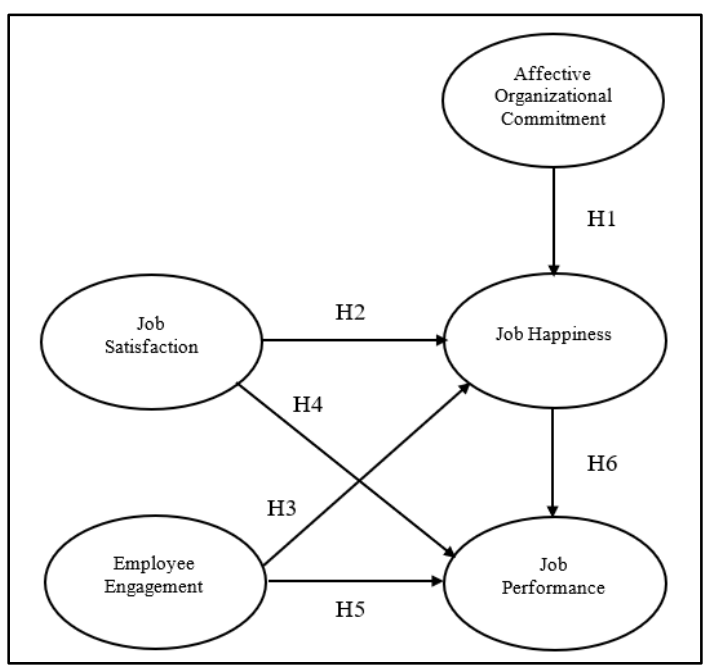

Fig. 1: Conceptual Model

\section{Research Methodology}

\subsection{Research Methodology and Measurement.}

Collecting data using a survey method by distributing online questionnaires. Measurements were carried out using the Likert scale of $1-7$ with criteria $(1=$ strongly disagree and $7=$ strongly agree). The measurement of the affective organizational commitment variable consists of eight questions adopted from De Waal [17]. The job satisfaction variable consists of ten questions adopted from Sarmiento et al. [119]. The employee engagement variable consists of eleven questions adopted from Saks [106]. The measurement of the job happiness variable consists of ten questions adopted from Czerw [158]. The job performance variable consists of eighteen questions adopted from Ramos et al. [159].

The respondents of this study were conducted by purposive sampling [160], while the sample criteria were employees of manufacturing companies with a minimum service period of two years in the Tangerang Industrial area, Indonesia. The data collection technique begins with distributing the initial questionnaire (pre-test) to 30 respondents. Then, the research was conducted quantitatively with the SEM (Structural Equation Model) method. At the pre-test, the researcher conducted a factor analysis to test the validity and reliability with SPSS. The validity test was carried out by looking at the measurement values of Kaiser-Meyer-Olkin (KMO) and Measure of Sampling Adequacy (MSA). The results of the KMO (0.730 to 0.821$)$ and MSA ( 0.620 to 0.933 ) values are more significant than 0.5 , which means that the factor analysis is appropriate. The reliability test uses Cronbach's Alpha measurement where the results are (0.924 to 0.974$)$ because it is closer to 1 , the better [161].

From the pre-test results using 57 questions with operational definitions of variables. Several questions are invalid: the affective organizational commitment variable, one question is declared invalid, the job satisfaction variable is three questions invalid, and the job happiness variable is one question is invalid. On the job performance variable, five questions were declared invalid, so that the invalid variables were ten variables. At the same time, the questions on the other variables were declared valid. So, what was said valid to be used as a questionnaire in this study were 47 questions.

Because it uses SEM where the determination of the number of research samples is at least 5 times the number of questions [162], the number of pieces in this study is 275 respondents by considering reserves if there is a discrepancy in filling out the questionnaire.

\section{Results}

A total of 275 respondents from 33 manufacturing companies found that male demography was $61.8 \%$ (170) and female was $38.2 \%$ (105). The age range is dominated by productive age, $88.4 \%$ (243). Meanwhile, the formal education of most respondents was senior high school, 75.3\% (207), diploma $3.6 \%$ (10\%), and undergraduate $19.6 \%$ (54). The position level is group leader $67.3 \%$ (185), supervisor $21.5 \%$ (59), supervisor $8.7 \%$ (24) and the rest is management $2.5 \%$ (7).

Based on the analysis of the suitability test, most of them showed a good match including $X^{\wedge} 2 / \mathrm{df}=$ 2.452 ; degree of freedom $=942$; Chi-Square $=$ 2432.11; $\mathrm{RMSEA}=0.073 ; \mathrm{ECVI}=9.45 ; \mathrm{AIC}=$ 2588,20; $\mathrm{CAIC}=3229,93 ; \mathrm{NFI}=0.94 ;$ Critical $\mathrm{N}=$ 118.83 and GFI $=0.73$. Thus, there is a fit of the overall model (Goodness of Fit) even though one model is at the marginal fit level. The results are as described in the PATH diagram in Figure 2. A hypothesis testing model can be displayed in Table 1 .

The results of the study are illustrated in the following T-Value diagram: 


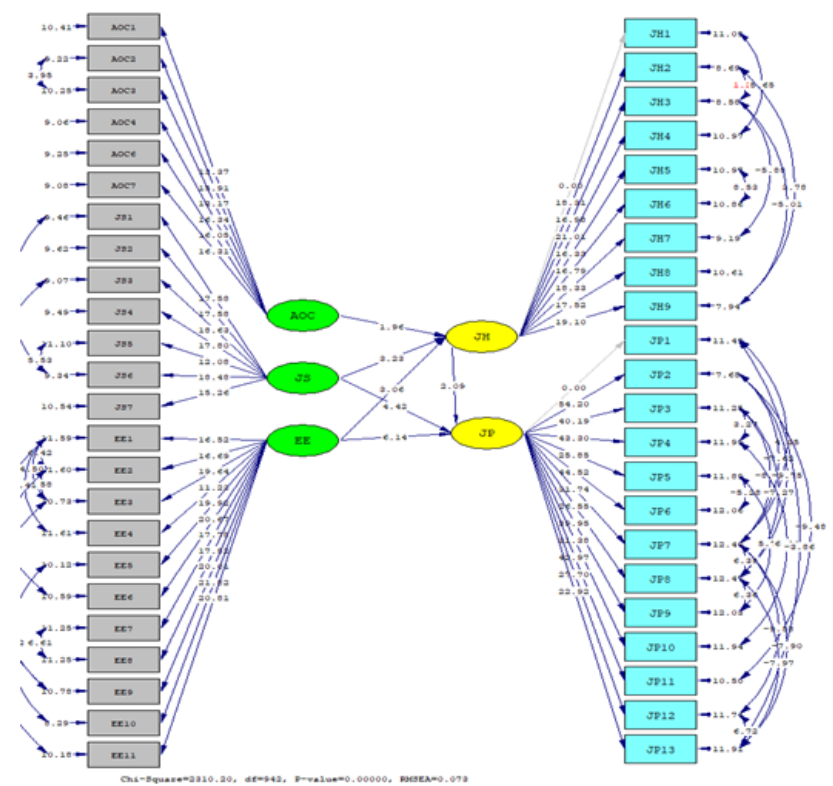

Fig. 2: Results of the T-Value Path Diagram

Based on the T-Value Path Diagram as shown in Figure 2 above, it is possible to present the hypothesis testing of the research model as follows:

\begin{tabular}{c|ccccc}
\multicolumn{3}{c}{ Table 1. Model Hypothesis Testing } \\
$\begin{array}{c}\text { Hypothesi } \\
\text { s }\end{array}$ & \multicolumn{3}{c}{ Relationship } & $\begin{array}{c}\text { T- } \\
\text { value }\end{array}$ & Remarks \\
\hline $\mathrm{H}_{1}$ & AOC & $\rightarrow$ & JH & 1,96 & Supports \\
$\mathrm{H}_{2}$ & JS & $\rightarrow$ & JH & 3,23 & Supports \\
$\mathrm{H}_{3}$ & EE & $\rightarrow$ & JH & 3,06 & Supports \\
$\mathrm{H}_{4}$ & JS & $\rightarrow$ & JP & 4,42 & Supports \\
$\mathrm{H}_{5}$ & EE & $\rightarrow$ & JP & 6,14 & Supports \\
$\mathrm{H} 6$ & JH & $\rightarrow$ & JP & 2,09 & Supports
\end{tabular}

Source: Lisrel 2021 processed data

Based on the hypothesis test table above, it is known that all have a T-Value value of 1.96. Thus the data in this study supports all the research hypotheses that were built.

\section{Discussion}

As explained in the introductory section, the purpose of this research has been to examine several important factors that are suspected to be factors that can lead to job happiness and job performance, namely affective organizational commitment, employee engagement, and job satisfaction. Hence the results of the study that all hypotheses can be accepted.

Affective organizational commitment to job happiness, according to the results obtained, that affective organizational commitment influences increasing job happiness and supports previous research [17]. The study found that affective organizational commitment to job happiness is indicated by the attitude of workers who proudly share positive things in the company that makes workers feel involved in solving problems within the company. By itself, workers feel valued through the results of their work, the efforts that have been created. Happiness is also indicated if workers can have the opportunity to develop through the opportunities provided by the company to improve their skills.

Another characteristic of happiness in the workplace is that employees feel their role is needed, improve their abilities, and work under their expertise. In addition, happiness can be reflected when employees can learn many things, feel that their work is important for the survival of the company, can rely on the support of colleagues, and of course, supported by a friendly workplace atmosphere. Job happiness will increase along with the increase in affective organizational commitment.

In its effect on job performance, the happiness obtained at work driven by affective organizational commitment becomes more influential. Workers who already feel attached to the company will feel happy with their work. It will encourage increased job performance so that job happiness can mediate affective organizational commitment to improving job performance.

Currently, with the development of information technology, the distribution of information is very fast. The slightest hint can easily be spread. Lousy information will undoubtedly harm or damage the reputation of the organization. Therefore, it is essential to have a synergistic relationship with the workers in manufacturing companies. There is an excellent emotional bond so that both parties can carry out their respective roles together. If workers already commit to supporting company programs such as work targets and productivity funds. Minor issues that can trigger conflicts, the decline in performance, and even the company's reputation can be avoided and minimized. 
Based on the results obtained in the study that job satisfaction influences increasing job happiness. It is in line with and supports previous research [14] [15] [11]. The study found that job satisfaction can be seen from the satisfaction of workers with their work due to the conditions of the work environment, support from colleagues, achievement of results during work, and awards from leaders at work locations. This pleasure causes workers to enjoy their work more so that there is a desire to update information that supports increasing skills continually. As a result, workers conclude that the job is suitable and appropriate, making the job happy.

The most important form of happiness is that employees can see their role in achieving the company's goals. So that the more satisfied workers feel because they had a role in achieving company goals, the more pleasure or happiness they will feel while at the work location. An example of that condition is like a car company had plans to achieve annual year sales, about 100 cars. One of the sales employees targeted the company to sell 20 cars. He can sell 25 cars in the closing year, and the company can achieve its company sales target. They can sell a total of 120 vehicles. The employee who can sell 25 cars will be satisfied because he can reach the company target and think that he has a role. In that case, that condition increases their happiness at work. Conversely, the employee who cannot sell more than their target sales will be dissatisfied with themselves, and it will decrease their happiness.

In its influence on job performance, satisfaction in the workplace makes workers try to complete it according to the time and targets that have been set. The desire to take on greater responsibilities, be involved in company activities, improvise in every work difficulty, try to find creative solutions, and only focus on positive issues are characteristics that can be seen in satisfied workers with their work. In line with increased job satisfaction, work results also increase. And complements the results of previous studies [18] - [21]; [155].

In the relationship between job satisfaction, job happiness, and job performance, based on the results, satisfaction will increase feelings of joy and simultaneously increase the desire of workers to improve work performance by the results found in the study. The atmosphere of a pleasant work environment triggers a sense of pleasure with his work. This feeling of pleasure is a positive response in the workplace. As a result, workers try to exert their efforts and abilities in responding to the targets set by the company. From this, job happiness can mediate between job satisfaction and job performance.

In a manufacturing company with workers who come from various backgrounds, including gender, education, years of service, and the number of thousands, employee satisfaction is significant. Every decision related to quality and quantity standards and product completion time, especially those that still rely on a labor-intensive system, is strongly influenced by the workers' emotional conditions. Small mistakes significantly affect the following work process, so a pleasant working atmosphere is good, safe production locations and pleasant, reliable co-workers and leaders will make workers enjoy their work. In this condition, workers feel happy to be at the work location, concentrate on the results, and do not complain about small things unrelated to the direct work. Instead, they are more about finding new ways to complete the work according to the target time. Some of the observable characteristics of satisfied and happy workers at work are avoiding unnecessary activities at the work location, for example, by spending time playing mobile phones, taking breaks over time, avoiding the problems at hand, and many more.

From what was obtained in this study, employee engagement influences job happiness and follows previous research [107]. The attachment of a worker at the work location can be seen when the worker is completely immersed in the work atmosphere, involved in achieving results, and concentrating at work. It becomes a joy when employees can play an active role in every activity in the company environment. Employee engagement cannot be separated from organizational goals, policies, or an organizational climate that is truly in favor of employees. There is a strong sense of bond that workers and the company have and need each other. It makes employees feel interested and want to stay in the company. So that the work that is the duty and obligation of a worker becomes lighter even though it takes up a lot of energy and attention.

And the effect of employee engagement is that happiness at work can be felt when workers like work, workers are involved in various activities within the company, and workers are physically and mentally present at work. This attachment cannot be separated from the nature of work and an attractive organizational climate that workers can feel directly 
so that an understanding of the meaning arises that their existence is considered and has meaning. This makes workers feel a voluntary attachment that makes them feel good at work. Moreover, with the presence of an extension that produces dedication, the tenacity of the worker becomes a joy that can be felt in the workplace.

In its influence with job performance, the attachment that employees have in dedication and persistence while at work, focusing on working becomes the principal capital for workers to make plans, solutions, and efforts to achieve targets so that workers have a lot of time to think about ways to fulfill their obligations as employees. On the other hand, the more attachment there is, the higher the desire to develop through work. When workers feel that challenges are not a burden, workers can easily see creative and innovative solutions in completing their tasks. Furthermore, it shows that work output also increases in line with employee engagement. These results support previous research [163].

In the relationship between employee engagement, job happiness, and job performance, based on the results, employee engagement will increase feelings of happiness and simultaneously support the desire of workers to improve work performance by the results found in the study. The bond between the company and the workers becomes a joy because there is a harmonious atmosphere with their respective responsibilities. Employees try to encourage the success of every plan and target of the organization with the belief that the company's achievements will impact improving their welfare. Feeling comfortable and happy with the organizational environment, especially the work that has been attached to the workers themselves, thinks that the company needs the expertise of workers, the results of work, so there is a desire to do optimally in every activity which of course has a significant contribution in improving work results. From this, job happiness can mediate between employee engagement and job performance.

By market dynamics, each company is currently competing to answer market demand. Failure to compete makes the company abandon customers because they cannot answer customer requests quickly. Companies must always be able to satisfy customers through the products they produce. Nonstandard quality, the number of orders that do not match will damage the company's good name if it happens repeatedly. Therefore, it becomes necessary that companies, especially manufacturing companies, must maintain good relations with their workers. If the relationship is well established, the company will quickly understand if workers must work overtime, work on holidays, and others. Without this attachment, it will be difficult for the company even though the wages paid are already high when working outside the typical working day. When workers feel there is an attachment, workers will voluntarily follow the company's targets and goals because they are afraid that the company's reputation is at stake, employees feel that their presence is needed, and their existence is not only a recipient of wages but rises to a higher level-namely work partners.

From the results obtained from the research, job happiness influences job performance. Some previous support studies support this finding [1] [18] - [21] [2]. This study found that the feeling of pleasure felt by workers increased awareness that the tasks performed were vital for the company. In the previous description, job happiness was found to mediate job satisfaction, affective organizational commitment, and employee engagement on job performance.

Pleasure in the work environment is an essential capital in achieving optimal work results from every worker. In addition to the previous description, the reflection of workers who feel happy while working always feels consciously and voluntarily bound to the company's targets and goals. Other than that, they have commitment and concentration, care about work results, work targets, and try to give maximum results to each activity to avoid repetitive work or improvements resulting in very low productivity. Workers will always be more responsive in every workplace rule and regulation, including work attitudes and standard operating procedures, complying with work safety rules. If the material and psychological needs are present in every work activity, from family to workplace, it can form concentration.

In the company's context, it is necessary to maintain and create a sense of comfort where the psychological needs of employees are met so that workers are ready to carry out their roles as workers. For example, suppose the employees feel threatened by the unprofessional manager conduct or feel stressed because of unrealistic work targets or unrealistic work hours. In that case, that condition will make the psychological needs of employees not 
fulfilled. As a result, it makes workers unable to perform their roles well.

\section{Conclusion}

The conclusion drawn from this research is that the six hypotheses were proved valid. The relationship in each of the variables proposed in the hypothesis is confirmed. The job happiness felt by workers at work is influenced by affective organizational commitment, job satisfaction, and employee engagement. And job performance is also influenced by job satisfaction, employee engagement, and job happiness. The calculation results found that employee engagement has the highest value, followed by job satisfaction, affecting job happiness and job performance. Therefore, it is important to pay attention to organizations, especially companies engaged in the manufacturing industry, to consistently evaluate and pay attention in every policymaking. As well as providing facilities that support the improvement of employee conditions regularly to ensure job satisfaction and job happiness are well controlled so that employees' job performance is maintained.

This research also has limitations that need improvement in the future. The first limitation is that the respondents come from several manufacturing companies with diverse products. Hence, future research should be done in similar manufacturing companies like manufacturing companies that just made shoes or steel. The second limitation is that in this study, the research respondents were employees from two different types of share ownership, namely private company and public company. Therefore, future research should consider making a study about the comparison between the two types of companies.

The third limitation is that this research is still tested by ignoring the demographic criteria of the respondents, so what needs to be done is to improve the analysis of how the effect of job happiness on enhancing performance based on the demographics of the respondents. In this case, the researcher suggests that future research study the impact of a demographic factor by adding demographic variables as moderation variables like gender, age, or income.

Acknowledgment:

This work was funded by a research grant from the Esa Unggul University, Indonesia.

\section{References:}

[1] W. Al-Ali, A. Ameen, O. Isaac, G. S. A. Khalifa, and A. H. Shibami, "The mediating effect of job happiness on the relationship between job satisfaction and employee performance and turnover intentions: A case study on the oil and gas industry in the United Arab Emirates," Journal of Business \& Retail Management Research, vol. 13, no. 04 , pp. 103-116, 2019, doi: 10.24052/jbrmr/v13is04/art-09.

[2] A. Salas-Vallina, J. Alegre, and R. Fernández Guerrero, "Happiness at work in knowledgeintensive contexts: Opening the research agenda," European Research on Management and Business Economics, vol. 24, no. 3, pp. 149-159, 2018, doi: 10.1016/j.iedeen.2018.05.003.

[3] R. Magnier-Watanabe, T. Uchida, P. Orsini, and C. Benton, "Organizational virtuousness and job performance in Japan: does happiness matter?" International Journal of Organizational Analysis, vol. 25, no. 4, pp. 628-646, 2017, doi: 10.1108/IJOA-10-2016-1074.

[4] Z. Jalali and A. Heidari, "The Relationship between Happiness, Subjective Well-Being, Creativity and Job Performance of Primary School Teachers in Ramhormoz City," International Education Studies, vol. 9, no. 6, p. 45, 2016, doi: 10.5539/ies.v9n6p45.

[5] W. Al-Ali, A. Ameen, O. Isaac, G. S. A. Khalifa, and A. H. Shibami, "The mediating effect of job happiness on the relationship between job satisfaction and employee performance and turnover intentions: A case study on the oil and gas industry in the United Arab Emirates," Journal of Business \& Retail Management Research, vol. 13, no. $\quad 04$, pp. 103-116, 2019, doi: 10.24052/jbrmr/v13is04/art-09.

[6] M. Nordenmark, "The Importance of Job and Family Satisfaction for Happiness among Women and Men in Different Gender Regimes," Societies, vol. 8, no. 1, p. 1, 2017, doi: 10.3390/soc8010001.

[7] K. W. Jensen, Y. Liu, and T. Schøtt, "Entrepreneur's innovation bringing job satisfaction, work-family balance, and life satisfaction: In China and around the world," International Journal of Innovation Studies, vol. 1, no. 4, pp. 193-206, 2017, doi: 10.1016/j.ijis.2017.11.002.

[8] K. adnan Bataineh, "Impact of Work-Life Balance, Happiness at Work, on Employee Performance," International Business Research, vol. 12, no. 2, p. 99, 2019, doi: 10.5539/ibr.v12n2p99.

[9] G. Gulyani and T. Sharma, "Total rewards components and work happiness in new ventures: The mediating role of work engagement," 
Evidence-based HRM, vol. 6, no. 3, pp. 255-271, 2018, doi: 10.1108/EBHRM-12-2017-0063.

[10] J. Barrena-Martínez, M. López-Fernández, and P. M. Romero-Fernández, "Socially responsible human resource policies and practices: Academic and professional validation," European Research on Management and Business Economics, vol. 23, no. 1 , pp. 55-61, 2017, doi: 10.1016/j.iedeen.2016.05.001.

[11] A. Salas-Vallina, J. Alegre Vidal, and R. Fernandez, "On the road to happiness at work (HAW): transformational leadership, organizational learning capability, and happiness at work," Personnel Review, vol. 46, no. 2, pp. 314-338, 2017.

[12] W. Tao, B. Song, M. A. Ferguson, and S. Kochhar, "Employees' prosocial behavioral intentions through empowerment in CSR decision-making," Public Relations Review, vol. 44, no. 5, pp. 667680, 2018, doi: 10.1016/j.pubrev.2018.07.002.

[13] M. Kiran and S. Khurram, "Flexitime and employee happiness at workplace: A quantitative study of software houses," Pakistan Journal of Commerce and Social Sciences (PJCSS), vol. 12, no. 3, pp. 1008-1024, 2018.

[14] A. B. Duche-Pérez and G. L. R. Galdos, "Job satisfaction and happiness in Peruvian nurses," Enfermeria Global, vol. 18, no. 2, pp. 353-373, 2019, doi: 10.6018/eglobal.18.2.334741.

[15] K. Yingyong and N. Rojniruttikul, "Workplace Happiness in Express International," pp. 3-9, 2019.

[16] S. Im, Y. W. Chung, and J. Y. Yang, "The mediating roles of happiness and cohesion in the relationship between employee volunteerism and job performance," International Journal of Environmental Research and Public Health, vol. 15, no. 12, 2018, doi: 10.3390/ijerph15122903.

[17] A. de Waal, "Increasing organizational attractiveness: The role of the HPO and happiness at work frameworks," Journal of Organizational Effectiveness, vol. 5, no. 2, pp. 124-141, 2018, doi: 10.1108/JOEPP-10-2017-0080.

[18] M. I. Hendri, "The mediation effect of job satisfaction and organizational commitment on the organizational learning effect of the employee performance," International Journal of Productivity and Performance Management, vol. 68, no. 7, pp. 1208-1234, 2019, doi: 10.1108/IJPPM-05-2018-0174.

[19] M. S. Mira, Y. V. Choong, and C. K. Thim, "The effect of HRM practices and employees' job satisfaction on employee performance," Management Science Letters, vol. 9, no. 6, pp. 771-786, 2019, doi: 10.5267/j.msl.2019.3.011.
[20] H. N. Ismail, A. Iqbal, and L. Nasr, "Employee engagement and job performance in Lebanon: the mediating role of creativity," International Journal of Productivity and Performance Management, vol. 68, no. 3, pp. 506-523, 2019, doi: 10.1108/IJPPM-02-2018-0052.

[21] I. A. P. W. Sugianingrat, S. R. Widyawati, C. A. D. J. da Costa, M. Ximenes, S. D. R. Piedade, and W. G. Sarmawa, "The employee engagement and OCB as mediating on employee performance," International Journal of Productivity and Performance Management, vol. 68, no. 2, pp. 319339, 2019, doi: 10.1108/IJPPM-03-2018-0124.

[22] J. P. Meyer and L. Herscovitch, "Commitment in the workplace: Toward a general model," Human Resource Management Review, vol. 11, no. 3, pp. 299-326, 2001, doi: 10.1016/S10534822(00)00053-X.

[23] L. Rhoades, R. Eisenberger, and S. Armeli, "Affective commitment to the organization: The contribution of perceived organizational support," Journal of Applied Psychology, vol. 86, no. 5, pp. 825-836, 2001, doi: 10.1037/0021-9010.86.5.825.

[24] N. J. Allen and J. P. Meyer, "The measurement and antecedents of affective, continuance and normative commitment to the organization," Journal of Occupational Psycholog, vol. 63, pp. $1-18,1990$.

[25] E. Alniaçik, Ü. Alniaçik, S. Erat, and K. Akçin, "Does Person-organization Fit Moderate the Effects of Affective Commitment and Job Satisfaction on Turnover Intentions?" Procedia Social and Behavioral Sciences, vol. 99, pp. 274281, 2013, doi: 10.1016/j.sbspro.2013.10.495.

[26] T. A. Wright and D. G. Bonett, "The moderating effects of employee tenure on the relation between organizational commitment and job performance: A meta-analysis," Journal of Applied Psychology, vol. 87, no. 6, pp. 1183-1190, 2002, doi: 10.1037/0021-9010.87.6.1183.

[27] R. Eisenberger et al., "Leader-Member Exchange and Affective Organizational Commitment: The Contribution of Supervisor's Organizational Embodiment," Journal of Applied Psychology, vol. 95, no. 6, pp. 1085-1103, 2010, doi: $10.1037 / \mathrm{a} 0020858$.

[28] T. A. Jackson, J. P. Meyer, and X. H. Wang, "Leadership, commitment, and culture: A metaanalysis," Journal of Leadership and Organizational Studies, vol. 20, no. 1, pp. 84-106, 2013, doi: 10.1177/1548051812466919.

[29] W. G. Kim, J. K. Leong, and Y. K. Lee, "Effect of service orientation on job satisfaction, organizational commitment, and intention of leaving in a casual dining chain restaurant," International Journal of Hospitality Management, 
vol. 24, no. 2, pp. 171-193, 2005, doi: 10.1016/j.ijhm.2004.05.004.

[30] C. Bulut and O. Culha, "The effects of organizational training on organizational commitment," International Journal of Training and Development, vol. 14, no. 4, pp. 309-322, 2010, doi: 10.1111/j.1468-2419.2010.00360.x.

[31] R. Cropanzano and M. S. Mitchell, "Social exchange theory: An Interdisciplinary Review," Journal of Management, vol. 31, no. 6, pp. 874900, 2005, doi: 10.1177/0149206305279602.

[32] K. Alfes and A. Shantz, "the Link Between Perceived Hrm, Engagement and Employee Behavior," Kingston Business \& Law Research Conference, pp. 1-40, 2011.

[33] A. Al Adresi and M. R. Darun, "Determining relationship between strategic human resource management practices and organizational commitment," International Journal of Engineering Business Management, vol. 9, pp. 19, 2017, doi: 10.1177/1847979017731669.

[34] M. Deery and L. Jago, "Revisiting talent management, work-life balance and retention strategies," International Journal of Contemporary Hospitality Management, vol. 27, no. 3, pp. 453472, 2015, doi: 10.1108/IJCHM-12-2013-0538.

[35] R. Ahmad, S. Ahmad, T. Islam, and A. Kaleem, "The nexus of corporate social responsibility (CSR), affective commitment and organizational citizenship behaviour in academia: A model of trust," Employee Relations, vol. 42, no. 1, pp. 232 247, 2020, doi: 10.1108/ER-04-2018-0105.

[36] W. Yvonne, R. H. A. Rahman, and C. S. Long, "Employee job satisfaction and job performance: A case study in a franchised retail-chain organization," Research Journal of Applied Sciences, Engineering and Technology, vol. 8, no. 17, pp. 1875-1883, 2014, doi: 10.19026/rjaset.8.1176.

[37] R. Sarmiento, J. Beale, and G. Knowles, "Determinants of performance amongst shop-floor employees: A preliminary investigation," Management Research News, vol. 30, no. 12, pp. 915-927, 2007, doi: $10.1108 / 01409170710833349$.

[38] R. Sarmiento, J. Beale, and G. Knowles, "Determinants of performance amongst shop-floor employees: A preliminary investigation," Management Research News, vol. 30, no. 12, pp. 915-927, 2007, doi: $10.1108 / 01409170710833349$.

[39] F. Luthans, "The need for and meaning of positive organizational behavior," Journal of Organizational Behavior, vol. 23, no. 6, pp. 695706, 2002, doi: 10.1002/job.165.
[40] W. G. Kim, J. K. Leong, and Y. K. Lee, "Effect of service orientation on job satisfaction, organizational commitment, and intention of leaving in a casual dining chain restaurant," International Journal of Hospitality Management, vol. 24, no. 2, pp. 171-193, 2005, doi: 10.1016/j.ijhm.2004.05.004.

[41] "Impact of job satisfaction on employee performance: An empirical study of autonomous Medical Institutions of Pakistan," African Journal of Business Management, vol. 6, no. 7, pp. 26972705, 2012, doi: 10.5897/AJBM11.2222.

[42] A. Furnham, A. Eracleous, and T. ChamorroPremuzic, "Personality, motivation and job satisfaction: Hertzberg meets the Big Five," Journal of Managerial Psychology, vol. 24, no. 8, pp. 2009, 265-779, doi: 10.1108/02683940910996789.

[43] S. D. Rosady and T. Y. R. Syah, "Work Satisfaction Antecedents and Consequences: An Analysis of Transformational Leadership Style, Communication and Performance of the Nurses (Study on the Hospital Nurses in Indonesia)," Iarjset, vol. 5, no. 9, pp. 59-65, 2018, doi: 10.17148/iarjset.2018.599.

[44] O. C. Hee, H. S. Yi, L. L. Ping, T. O. Kowang, and G. C. Fei, "Factors Influencing Job Satisfaction in the Palm Oil Industry in Malaysia," International Journal of Academic Research in Business and Social Sciences, vol. 9, no. 2, pp. 516-527, 2019, doi: 10.6007/ijarbss/v9-i2/5584.

[45] M. T. Tessema and J. L. Soeters, "Challenges and prospects of HRM in developing countries: Testing the HRM-performance link in the Eritrean civil service," International Journal of Human Resource Management, vol. 17, no. 1, pp. 86-105, 2006, doi: 10.1080/09585190500366532.

[46] A. N. Nguyen, J. Taylor, and S. Bradley, "Working Paper Relative pay and job satisfaction: some new evidence," management, no. February 2003.

[47] Nastohar and R. Anindita, "Transformation Employee Performance During Leadership Motivation Effect Over Kansai Prakarsa Coatings Company," Journal of Multidisciplinary Academic, vol. 01, no. 01, pp. 27-30, 2019.

[48] A. P. Brief and H. M. Weiss, "Organizational Behavior: Affect in the Workplace ORGANIZATIONAL BEHAVIOR: Affect in the Workplace," Аnnu. Rev. Psychol, no. February 2002, pp. 279-307, 2017.

[49] X. Wu, "Factors influencing employee turnover intention in the Malaysian retail industry," 2018.

[50] B. Aziri, "Job Satisfaction, a Literature Review," Management research and practice, vol. 3, no. 1, pp. 77-90, 2011. 
[51] J. N. Islam, H. K. Mohajan, and R. Datta, "A study on Job Satisfaction and Morale of a Commercial Banks in Bangladesh," International Journal of Economics and Research, vol. 3, no. 4, pp. 153173, 2012.

[52] A. M. Saks, "Antecedents and consequences of employee engagement," Journal of Managerial Psychology, vol. 21, no. 7, pp. 600-619, 2006, doi: 10.1108/02683940610690169.

[53] A. M. Saks, "Antecedents and consequences of employee engagement revisited," Journal of Organizational Effectiveness, vol. 6, no. 1, pp. 1938, 2019, doi: 10.1108/JOEPP-06-2018-0034.

[54] P. E. Anthony-McMann, A. D. Ellinger, M. Astakhova, and J. R. B. Halbesleben, "Exploring Different Operationalizations of Employee Engagement and Their Relationships with Workplace Stress and Burnout," Computational Complexity, 2016, doi: 10.1002/hrdq.

[55] L. Sun and C. Bunchapattanasakda, "Employee Engagement: A Literature Review," International Journal of Human Resource Studies, vol. 9, no. 1, p. 63, 2019, doi: 10.5296/ijhrs.v9i1.14167.

[56] J. K. Harter, F. L. Schmidt, and C. L. M. Keyes, "Well-being in the workplace and its relationship to business outcomes: A review of the Gallup studies.," Flourishing: Positive psychology and the life well-lived., no. December 2013, pp. 205-224, 2004, doi: 10.1037/10594-009.

[57] W. B. Schaufeli and A. B. Bakker, "Job demands, job resources, and their relationship with burnout and engagement: A multi-sample study," Journal of Organizational Behavior, vol. 25, no. 3, pp. 293-315, 2004, doi: 10.1002/job.248.

[58] P. Beatty, Psychology Carleton University Ottawa, Ontario C2011 Peter Beatty. 2011.

[59] H. A. Witemeyer, "ScholarWorks @ Georgia State University," 2013.

[60] P. Kazimoto, "Employee Engagement and Organizational Performance of Retails Enterprises," American Journal of Industrial and Business Management, vol. 06, no. 04, pp. 516525, 2016, doi: 10.4236/ajibm.2016.64047.

[61] W. H. Macey and B. Schneider, " $<$ Macey \& Schneider. (2008). The Meaning of Employee Engagement.pdf $>$," Industrial and Organizational Psychology, vol. 1, pp. 3-30, 2008.

[62] A. Czerw, "Diagnosing Well-Being in Work Context - Eudemonic Well-Being in the Workplace Questionnaire," Current Psychology, vol. 38, no. 2, pp. 331-346, Apr. 2019, doi: 10.1007/s12144-017-9614-8.

[63] R. Biswas-Diener, T. B. Kashdan, and L. A. King, "Two traditions of happiness research, not two distinct types of happiness," Journal of Positive
Psychology, vol. 4, no. 3, pp. 208-211, 2009, doi: 10.1080/17439760902844400.

[64] P. O. Wesarat, M. Y. Sharif, and A. H. A. Majid, "A conceptual framework of happiness at the workplace," Asian Social Science, vol. 11, no. 2, pp. 78-88, 2015, doi: 10.5539/ass.v11n2p78.

[65] S. Moccia, "Happiness at work," Papeles del Psicologo, vol. 37, no. 2, pp. 143-151, 2016, doi: 10.1002/9780470666845.oth1.

[66] A. Czerw, "Well-Being at Work - the Essence, Causes and Consequences of the Phenomenon," International Journal of Contemporary Management, vol. 13, no. 2, 2014, doi: 10.5604/16435494.1130808.

[67] P. J. Ramos-Villagrasaa, J. R. Barradaa, E. Fernández-del-Ríoa, and L. Koopmans, "Job performance is considered the "ultimate dependent variable' in human resource management, turning its assessment into a capital issue. The present study analyzes the functioning of a brief 18 -item self-report scale, the Individual Work Performance Que," Journal of Work and Organizational Psychology, 2019.

[68] J. P. Campbell and B. M. Wiernik, The Modeling and Assessment of Work Performance, vol. 2. 2015. doi: 10.1146/annurev-orgpsych-032414111427.

[69] L. Koopmans, C. M. Bernaards, V. H. Hildebrandt, D. Lerner, C. W. De Vet Henrica, and A. J. Van Der Beek, "Koopmansetal2016CrossculturaladaptationoftheIWPQ.pdf." 2015.

[70] R. K. Pradhan and L. K. Jena, "Employee Performance at Workplace: Conceptual Model and Empirical Validation," Business Perspectives and Research, vol. 5, no. 1, pp. 69-85, 2017, doi: 10.1177/2278533716671630.

[71] A. Yahaya and J. Ramli, "FACTORS THAT CONTRIBUTED STRESS AMONG SECONDARY SCHOOL TEACHERS IN FOUR STATES IN MALAYSIA," Asia Pacific Journal of Educators and Education, Vol. 25, 103-136, 2010, vol. 25, pp. 103-136, 2010.

[72] M. H. K. Naghneh, M. Z. Tafreshi, M. Naderi, N. Shakeri, F. Bolourchifrad, and N. S. Goyaghaj, "The relationship between organizational commitment and nursing care behavior," Electronic Physician, vol. 9, no. 7, pp. 4385-4840, 2017.

[73] M. Halter et al., "The determinants and consequences of adult nursing staff turnover: A systematic review of systematic reviews," $B M C$ Health Services Research, vol. 17, no. 1, pp. 1-20, 2017, doi: 10.1186/s12913-017-2707-0.

[74] P. W. Hom, T. W. Lee, J. D. Shaw, and J. P. Hausknecht, "One hundred years of employee turnover theory and research," Journal of Applied 
Psychology, vol. 102, no. 3, pp. 530-545, 2017, doi: 10.1037/apl0000103.

[75] S. Singh and Y. Aggarwal, "Happiness at Work Scale: Construction and Psychometric Validation of a Measure Using Mixed Method Approach," Journal of Happiness Studies, vol. 19, no. 5, pp. 1439-1463, 2018, doi: 10.1007/s10902-017-9882$\mathrm{x}$.

[76] S. M. Elias, "Employee commitment in times of change: Assessing the importance of attitudes toward organizational change," Journal of Management, vol. 35, no. 1, pp. 37-55, 2009, doi: 10.1177/0149206307308910.

[77] J. E. Mathieu and D. M. Zajac, "A Review and meta-analysis of the antecedents, correlates, and consequences of organizational commitment," Psychological Bulletin, vol. 108, no. 2, pp. 171194, 1990, doi: 10.1037/0033-2909.108.2.171.

[78] J. P. Meyer, D. J. Stanley, L. Herscovitch, and L. Topolnytsky, "Affective, continuance, and normative commitment to the organization: A meta-analysis of antecedents, correlates, and consequences," Journal of Vocational Behavior, vol. 61, no. 1, pp. 20-52, 2002, doi: 10.1006/jvbe.2001.1842.

[79] I. Mihajlović, C. Djevojić, and M. Stanković, "Key drivers of internal market changes and innovative tools towards an efficient business climate," WSEAS Transactions on Systems and Control, vol. 16, pp. 224-243, 2021, doi: 10.37394/23203.2021.16.19.

[80] M. H. K. Naghneh, M. Z. Tafreshi, M. Naderi, N. Shakeri, F. Bolourchifrad, and N. S. Goyaghaj, "The relationship between organizational commitment and nursing care behavior," Electronic Physician, vol. 9, no. 7, pp. 4385-4840, 2017.

[81] K. Truss, E. Soane, R. Delbridge, K. Alfes, A. Shantz, and G. Petrov, "Employee engagement, organizational performance, and individual wellbeing: exploring the evidence, developing the theory," The International Journal of Human Resource Management, vol. 22, no. 1, pp. 232233, 2011, doi: 10.1080/09585192.2011.552282.

[82] A. Al Adresi and M. R. Darun, "Determining relationship between strategic human resource management practices and organizational commitment," International Journal of Engineering Business Management, vol. 9, pp. 19, 2017, doi: 10.1177/1847979017731669.

[83] M. Deery and L. Jago, "Revisiting talent management, work-life balance and retention strategies," International Journal of Contemporary Hospitality Management, vol. 27, no. 3, pp. 453472, 2015, doi: 10.1108/IJCHM-12-2013-0538.
[84] T. A. Jackson, J. P. Meyer, and X. H. Wang, "Leadership, commitment, and culture: A metaanalysis," Journal of Leadership and Organizational Studies, vol. 20, no. 1, pp. 84-106, 2013, doi: $10.1177 / 1548051812466919$.

[85] R. Cropanzano and M. S. Mitchell, "Social exchange theory: An Interdisciplinary Review," Journal of Management, vol. 31, no. 6, pp. 874900, 2005, doi: 10.1177/0149206305279602.

[86] C. D. Fisher, "Happiness at Work," International Journal of Management Reviews, vol. 12, no. 4, pp. $\quad 384-412, \quad 2010$, doi: 10.1111/j.14682370.2009.00270.x.

[87] M. Yan and K. Shi, "Subjective Well-Being and Job Types: New Evidence from China," Economics and Culture, vol. 16, no. 1, pp. 24-31, 2019, doi: 10.2478/jec-2019-0003.

[88] A. Awang, I. I. Ibrahim, M. N. Md Nor, M. F. Mohd Razali, Z. Mat Arof, and A. R. Abdul Rahman, "Academic Factors and Turnover Intention: Impact of Organization Factors," Higher Education Studies, vol. 5, no. 3, pp. 24-44, 2015, doi: 10.5539/hes.v5n3p24.

[89] D. M. Govender, “AN INVESTIGATION INTO JOB SATISFACTION AND EMPLOYEE PERFORMANCE AT STODELS RETAIL NURSERIES- A CASE STUDY," no. September 2013, 2013.

[90] $\mathrm{Wu}$ and Xiangping, "Factors Influencing Employee Turnover Intention: The Case of Retail Industry in Bangkok, Thailand," My base paper, vol. 3, p. 108, 2012.

[91] O. C. Hee, H. S. Yi, L. L. Ping, T. O. Kowang, and G. C. Fei, "Factors Influencing Job Satisfaction in the Palm Oil Industry in Malaysia," International Journal of Academic Research in Business and Social Sciences, vol. 9, no. 2, pp. 516-527, 2019, doi: 10.6007/ijarbss/v9-i2/5584.

[92] M. T. Tessema and J. L. Soeters, "Challenges and prospects of HRM in developing countries: Testing the HRM-performance link in the Eritrean civil service," International Journal of Human Resource Management, vol. 17, no. 1, pp. 86-105, 2006, doi: 10.1080/09585190500366532.

[93] A. N. Nguyen, J. Taylor, and S. Bradley, "Working Paper Relative pay and job satisfaction: some new evidence," management, no. February 2003.

[94] A. Katrodia, "Job stress and insecurity among the employees in food delivery services," WSEAS Transactions on Environment and Development, vol. 16, pp. 708-717, 2020, doi: 10.37394/232015.2020.16.73.

[95] A. P. Brief and H. M. Weiss, "Organizational Behavior: Affect in the Workplace ORGANIZATIONAL BEHAVIOR: Affect in the 
Workplace," Аnnu. Rev. Psychol, no. February 2002, pp. 279-307, 2017.

[96] X. Wu, "Factors influencing employee turnover intention in the Malaysian retail industry," 2018.

[97] B. Aziri, "Job Satisfaction, a Literature Review," Management research and practice, vol. 3, no. 1, pp. 77-90, 2011.

[98] L. C. Walsh, J. K. Boehm, and S. Lyubomirsky, "Does Happiness Promote Career Success? Revisiting the Evidence," Journal of Career Assessment, vol. 26, no. 2, pp. 199-219, 2018, doi: $10.1177 / 1069072717751441$.

[99] M. Tadić, A. B. Bakker, and W. G. M. Oerlemans, "Work happiness among teachers: A day reconstruction study on the role of selfconcordance," Journal of School Psychology, vol. 51, no. 6, pp. 735-750, 2013, doi: 10.1016/j.jsp.2013.07.002.

[100] P. O. Wesarat, M. Y. Sharif, and A. H. A. Majid, "A conceptual framework of happiness at the workplace," Asian Social Science, vol. 11, no. 2, pp. 78-88, 2015, doi: 10.5539/ass.v11n2p78.

[101] A. Singh and B. Gupta, "Commitment, Professional Commitment, and Team Commitment - A Study of Benchmarking: An International Journal Article information," Benchmarking: An International Journal, vol. 22, no. January 2015, p. 1192, 2016.

[102] E. Karanges, K. Johnston, A. Beatson, and I. Lings, "The influence of internal communication on employee engagement: A pilot study," Public Relations Review, vol. 41, no. 1, pp. 129-131, 2014, doi: 10.1016/j.pubrev.2014.12.003.

[103] J. K. Harter, F. L. Schmidt, and T. L. Hayes, "Business-unit-level relationship between employee satisfaction, employee engagement, and business outcomes: A meta-analysis," Journal of Applied Psychology, vol. 87, no. 2, pp. 268-279, 2002, doi: 10.1037/0021-9010.87.2.268.

[104] K. Mishra, L. Boynton, and A. Mishra, "Driving Employee Engagement: The Expanded Role of Internal Communications," International Journal of Business Communication, vol. 51, pp. 183-202, 2014, doi: 10.1177/2329488414525399.

[105] A. B. Bakker and E. Demerouti, "Towards a model of work engagement," Career Development International, vol. 13, no. 3, pp. 209-223, 2008, doi: $10.1108 / 13620430810870476$.

[106] A. M. Saks, "Antecedents and consequences of employee engagement revisited," Journal of Organizational Effectiveness, vol. 6, no. 1, pp. 1938, 2019, doi: 10.1108/JOEPP-06-2018-0034.

[107] N. Santhanam and S. Srinivas, "Modeling the impact of employee engagement and happiness on burnout and turnover intention among blue-collar workers at a manufacturing company,"
Benchmarking, vol. 27, no. 2, pp. 499-516, 2020, doi: 10.1108/BIJ-01-2019-0007.

[108] K. Okta, N. Umar, AlMusadiq, N. Utami, and Hamidah, "The Influence of Organizational Culture and Entrepreneurial Orientation on the Job Satisfaction, Organizational Commitment, and Employee 's Performance," vol. 7, no. 2, pp. 5568, 2015.

[109] Y. Markovits, D. Boer, and R. van Dick, "Economic crisis and the employee: The effects of economic crisis on employee job satisfaction, commitment, and self-regulation," European Management Journal, vol. 32, no. 3, pp. 413-422, 2014, doi: 10.1016/j.emj.2013.09.005.

[110] M. I. Hendri, "The mediation effect of job satisfaction and organizational commitment on the organizational learning effect of the employee performance," International Journal of Productivity and Performance Management, vol. 68, no. 7, pp. 1208-1234, 2019, doi: 10.1108/IJPPM-05-2018-0174.

[111] M. Sony and N. Mekoth, "The relationship between workplace spirituality, job satisfaction and job performance," International Journal of Process Management and Benchmarking, vol. 9, no. 1 , pp. 27-46, 2019, doi: 10.1504/IJPMB.2019.097819.

[112] A. E. Ellinger, D. J. Ketchen, G. T. M. Hult, A. B. Elmadağ, and R. G. Richey, "Market orientation, employee development practices, and performance in logistics service provider firms," Industrial Marketing Management, vol. 37, no. 4, pp. 353366, 2008, doi: 10.1016/j.indmarman.2007.01.002.

[113] B. J. Babin and J. S. Boles, "The effects of perceived co-worker involvement and supervisor support on service provider role stress, performance and job satisfaction," Journal of Retailing, vol. 72 , no. 1, pp. 57-75, 1996, doi: 10.1016/S0022-4359(96)90005-6.

[114] S. D. Rosady and T. Y. R. Syah, "Work Satisfaction Antecedents and Consequences: An Analysis of Transformational Leadership Style, Communication and Performance of the Nurses (Study on the Hospital Nurses in Indonesia)," Iarjset, vol. 5, no. 9, pp. 59-65, 2018, doi: 10.17148/iarjset.2018.599.

[115] A. Vorina, M. Simonič, and M. Vlasova, "An Analysis of the Relationship Between Job Satisfaction and Employee Engagement," Economic Themes, vol. 55, no. 2, pp. 243-262, 2017, doi: 10.1515/ethemes-2017-0014.

[116] D. Guest, "Flexible employment contracts, the psychological contract and employee outcomes: An analysis and review of the evidence," International Journal of Management Reviews, 
vol. 5-6, no. 1, pp. 1-19, 2004, doi: 10.1111/j.1460-8545.2004.00094.x.

[117] S. H. Abualoush, A. M. Obeidat, A. Tarhini, R. Masa'deh, and A. Al-Badi, "The role of employees' empowerment as an intermediary variable between knowledge management and information systems on employees' performance," VINE Journal of Information and Knowledge Management Systems, vol. 48, no. 2, pp. 217-237, 2018, doi: 10.1108/VJIKMS-08-2017-0050.

[118] J. Anitha, "Determinants of employee engagement and their impact on employee performance," International Journal of Productivity and Performance Management, vol. 63, no. 3, pp. 308323, 2014, doi: 10.1108/IJPPM-01-2013-0008.

[119] R. Sarmiento, J. Beale, and G. Knowles, "Determinants of performance amongst shop-floor employees: A preliminary investigation," Management Research News, vol. 30, no. 12, pp. 915-927, 2007, doi: $10.1108 / 01409170710833349$.

[120] M. I. Taba, "Mediating effect of work performance and organizational commitment in the relationship between reward system and employees' work satisfaction," Journal of Management Development, vol. 37, no. 1, pp. 65-75, 2018, doi: 10.1108/JMD-11-2016-0256.

[121] D. Zeglat and S. Janbeik, "Meaningful work and organizational outcomes: The mediating role of individual work performance," Management Research Review, vol. 42, no. 7, pp. 859-878, 2019, doi: 10.1108/MRR-05-2018-0206.

[122] Q. H. Do, A. T. Tran, and T. T. The "Financial systems theory and control of finances: The mediating role of psychological empowerment in the relationship between transformational leadership and employee engagement: An evidence from Vietnam," WSEAS Transactions on Systems and Control, vol. 15, pp. 655-664, 2020, doi: 10.37394/23203.2020.15.65.

[123] W. B. Schaufeli and A. B. Bakker, "Job demands, job resources, and their relationship with burnout and engagement: A multi-sample study," Journal of Organizational Behavior, vol. 25, no. 3, pp. 293-315, 2004, doi: 10.1002/job.248.

[124] J. K. Harter, F. L. Schmidt, and C. L. M. Keyes, "Well-being in the workplace and its relationship to business outcomes: A review of the Gallup studies.," Flourishing: Positive psychology and the life well-lived., no. December 2013, pp. 205-224, 2004, doi: 10.1037/10594-009.

[125] P. Beatty, Psychology Carleton University Ottawa, Ontario (C2011 Peter Beatty. 2011.

[126] S. Xu, Y. Choi, and Q. Lv, "Subjective WellBeing, Work Motivation and Organizational Commitment of Chinese Hotel Frontline
Employees: A Moderated Mediation Study," Journal of Tourism Research \& Hospitality, vol. 03, no. 02, 2014, doi: 10.4172/23248807.1000137.

[127] W. B. Schaufeli, A. B. Bakker, and M. Salanova, "The measurement of work engagement with a short questionnaire: A cross-national study," Educational and Psychological Measurement, vol. 66, no. 4, pp. 701-716, 2006, doi: $10.1177 / 0013164405282471$.

[128] A. B. Bakker, E. Demerouti, and A. I. SanzVergel, "Burnout and Work Engagement: The JDR Approach," Annual Review of Organizational Psychology and Organizational Behavior, vol. 1, pp. 389-411, 2014, doi: 10.1146/annurevorgpsych-031413-091235.

[129] A. de Waal, "Increasing organisational attractiveness: The role of the HPO and happiness at work frameworks," Journal of Organizational Effectiveness, vol. 5, no. 2, pp. 124-141, 2018, doi: 10.1108/JOEPP-10-2017-0080.

[130] E. Suryanto, T. Y. R. Syah, D. A. Negoro, and S. Pusaka, "Transformational Leadership Style and Work Life Balance: The Effect on Employee Satisfaction Through Employee Engagement," Russian Journal of Agricultural and SocioEconomic Sciences, vol. 91, no. 7, pp. 310-318, 2019, doi: 10.18551/rjoas.2019-07.36.

[131] J. F. Hopstaken, D. Van Der Linden, and A. B. Bakker, "Correction: Shifts in attention during mental fatigue: Evidence from subjective, behavioral, physiological, and eye-tracking data [Journal of Experimental Psychology: Human Perception and Performance, 42, 6, (2016), (878889)], doi: 10.1037/xhp0000189," Journal of Experimental Psychology: Human Perception and Performance, vol. 42, no. 9, p. 1442, 2016, doi: 10.1037/xhp0000300.

[132] S. L. Albrecht, A. B. Bakker, J. A. Gruman, W. H. Macey, and A. M. Saks, "Employee engagement, human resource management practices and competitive advantage: An integrated approach," Journal of Organizational Effectiveness, vol. 2, no. 1, pp. 7-35, 2015, doi: 10.1108/JOEPP-08-20140042.

[133] J. F. Hopstaken, D. van der Linden, A. B. Bakker, and M. A. J. Kompier, "A multifaceted investigation of the link between mental fatigue and task disengagement," Psychophysiology, vol. 52, no. 3, pp. 305-315, 2015, doi: 10.1111/psyp.12339.

[134] R. Chiva and J. Alegre, "Organizational learning capability and job satisfaction: An empirical assessment in the ceramic tile industry," British Journal of Management, vol. 20, no. 3, pp. 323- 
$340, \quad 2009, \quad$ doi: $\quad 10.1111 /$ j.14678551.2008.00586.x.

[135] S. Cartwright and N. Holmes, "The meaning of work: The challenge of regaining employee engagement and reducing cynicism," Human Resource Management Review, vol. 16, no. 2, pp. 199-208, 2006, doi: 10.1016/j.hrmr.2006.03.012.

[136] D. A. Garvin, A. C. Edmondson, and F. Gino, "Is Yours a Learning Organization? - Harvard Business Review," Harvard Business Review, pp. $1-10,2008$.

[137] M. F. Dollard and A. B. Bakker, "Psychosocial safety climate as a precursor to conducive work environments, psychological health problems, and employee engagement," Journal of Occupational and Organizational Psychology, vol. 83, no. 3, pp. 579-599, 2010, doi: 10.1348/096317909X470690.

[138] A. Carmeli, D. Brueller, and J. E. Dutton, "Learning behaviours in the workplace: The role of high-quality interpersonal relationships and psychological safety," Systems Research and Behavioral Science, vol. 26, no. 1, pp. 81-98, 2009, doi: 10.1002/sres.932.

[139] O. Tregaskis, K. Daniels, L. Glover, P. Butler, and M. Meyer, "High Performance Work Practices and Firm Performance: A Longitudinal Case Study," British Journal of Management, vol. 24, no. 2, pp. 225-244, 2013, doi: 10.1111/j.14678551.2011.00800.x.

[140] A. B. Bakker, H. Van Emmerik, and P. van Riet, "How job demands, resources, and burnout predict objective performance: A constructive replication," Anxiety, Stress and Coping, vol. 21, no. 3, pp. 309-324, 2008, doi: 10.1080/10615800801958637.

[141] J. P. Campbell and B. M. Wiernik, The Modeling and Assessment of Work Performance, vol. 2. 2015. doi: 10.1146/annurev-orgpsych-032414111427.

[142] M. Kiran and S. Khurram, "Flexitime and employee happiness at workplace: A quantitative study of software houses," Pakistan Journal of Commerce and Social Sciences (PJCSS), vol. 12, no. 3, pp. 1008-1024, 2018.

[143] A. B. Bakker and E. Demerouti, "Multiple Levels in Job Demands - Resources Theory: Implications for Employee Well-being and Performance," Handbook of well-being, no. 2018, pp. 1-13, 2018.

[144] E. Demerouti, A. B. Bakker, and J. M. P. Gevers, "Job crafting and extra-role behavior: The role of work engagement and flourishing," Journal of Vocational Behavior, vol. 91, pp. 87-96, 2015, doi: 10.1016/j.jvb.2015.09.001.

[145] M. van den Heuvel, E. Demerouti, and M. C. W. Peeters, "The job crafting intervention: Effects on job resources, self-efficacy, and affective well- being," Journal of Occupational and Organizational Psychology, vol. 88, no. 3, pp. 511-532, 2015, doi: 10.1111/joop.12128.

[146] J. van Wingerden, A. B. Bakker, and D. Derks, "A test of a job demands-resources intervention," Journal of Managerial Psychology, vol. 31, no. 3, pp. 686-701, 2016, doi: 10.1108/JMP-03-20140086.

[147] A. B. Bakker, H. Van Emmerik, and P. Van Riet, "How job demands, resources, and burnout predict objective performance: A constructive replication," Anxiety, Stress and Coping, vol. 21, no. 3, pp. 309-324, 2008, doi: $10.1080 / 10615800801958637$.

[148] G. R. Slemp, M. L. Kern, and D. A. VellaBrodrick, "Workplace Well-Being: The Role of Job Crafting and Autonomy Support," Psychology of Well-Being, vol. 5, no. 1, 2015, doi: 10.1186/s13612-015-0034-y.

[149] S. Chang, K. Han, and Y. Cho, "Association of happiness and nursing work environments with job crafting among hospital nurses in South Korea," International Journal of Environmental Research and Public Health, vol. 17, no. 11, pp. 1-9, 2020, doi: 10.3390/ijerph17114042.

[150] G. R. Slemp, M. L. Kern, and D. A. VellaBrodrick, "Workplace Well-Being: The Role of Job Crafting and Autonomy Support," Psychology of Well-Being, vol. 5, no. 1, 2015, doi: 10.1186/s13612-015-0034-y.

[151] A. Awang, I. I. Ibrahim, M. N. Md Nor, M. F. Mohd Razali, Z. Mat Arof, and A. R. Abdul Rahman, "Academic Factors and Turnover Intention: Impact of Organization Factors," Higher Education Studies, vol. 5, no. 3, pp. 24-44, 2015, doi: 10.5539/hes.v5n3p24.

[152] K. Daniels, "Measures of five aspects of affective well-being at work," Human Relations, vol. 53, no. 2, pp. 275-294, 2000, doi: 10.1177/a010564.

[153] I. Silla, F. J. Gracia, and J. M. Peiró, "Job insecurity and health-related outcomes among different types of temporary workers," Economic and Industrial Democracy, vol. 26, no. 1, pp. 89117, 2005, doi: 10.1177/0143831X05049404.

[154] E. Demerouti, A. B. Bakker, and J. M. P. Gevers, "Job crafting and extra-role behavior: The role of work engagement and flourishing," Journal of Vocational Behavior, vol. 91, pp. 87-96, 2015, doi: 10.1016/j.jvb.2015.09.001.

[155] A. A. Muna, A. A. Zain, and G. Dr. Shaju, "Job Satisfaction and Employee Performance: a Theoretical Review of the Relationship Between the Two Variables," International Journal of Advanced Research, vol. 943, no. 1, pp. 1-20, 2017. 
[156] M. van den Heuvel, E. Demerouti, and M. C. W. Peeters, "The job crafting intervention: Effects on job resources, self-efficacy, and affective wellbeing," Journal of Occupational and Organizational Psychology, vol. 88, no. 3, pp. 511-532, 2015, doi: 10.1111/joop.12128.

[157] J. van Wingerden, A. B. Bakker, and D. Derks, "A test of a job demands-resources intervention," Journal of Managerial Psychology, vol. 31, no. 3, pp. 686-701, 2016, doi: 10.1108/JMP-03-20140086.

[158] A. Czerw, "Diagnosing Well-Being in Work Context - Eudemonic Well-Being in the Workplace Questionnaire," Current Psychology, vol. 38, no. 2, pp. 331-346, 2019, doi: 10.1007/s12144-017-9614-8.

[159] P. J. Ramos-Villagrasa, J. R. Barrada, E. Fernández-Del-Río, and L. Koopmans, "Assessing job performance using brief self-report scales: The case of the individual work performance questionnaire," Revista de Psicologia del Trabajo y de las Organizaciones, vol. 35, no. 3, pp. 195205, 2019, doi: 10.5093/jwop2019a21.

[160] I. Etikan, "Comparison of Convenience Sampling and Purposive Sampling," American Journal of Theoretical and Applied Statistics, vol. 5, no. 1, p. 1, 2016, doi: 10.11648/j.ajtas.20160501.11.

[161] J. Hair, W. Black, B. Babin, and R. Anderson, Multivariate Data Analysis (MVDA). 2014. doi: 10.1002/9781118895238.ch8.

[162] J. Hair, W. Black, B. Babin, and R. Anderson, Multivariate Data Analysis (MVDA). 2014. doi: 10.1002/9781118895238.ch8.

[163] M. Kiran and S. Khurram, "Flexitime and employee happiness at workplace: A quantitative study of software houses," Pakistan Journal of Commerce and Social Sciences (PJCSS), vol. 12, no. 3, pp. 1008-1024, 2018.
Sources of Funding for Research Presented in a Scientific Article or Scientific Article Itself

This work was funded by a research grant from the Esa Unggul University, Indonesia.

\section{Creative Commons Attribution License 4.0 (Attribution 4.0 International, CC BY 4.0)}

This article is published under the terms of the Creative Commons Attribution License 4.0

https://creativecommons.org/licenses/by/4.0/deed.en_ 